\title{
Leadership as an Act of Love: Leading in Dangerous Times
}

\author{
Mónica C. Byrne-Jiménez ${ }^{1 *}$ and Irene H. Yoon ${ }^{2}$ \\ ${ }^{1}$ Educational Leadership and Policy Studies, Indiana University, Bloomington, IN, United States, ${ }^{2}$ Educational Leadership \\ and Policy, University of Utah, Salt Lake City, UT, United States
}

This essay is an invitation to engage in a heart-whole thought experiment around the possibilities and potential of framing leadership as an act of love. The current school context is defined by increasing pressures and demands that undermines the humanity of leaders, children and educators. In this context, leaders must find other ways to lead. The authors propose a framework offered to help leaders to reconnect with their love of children and education. They define the "habits of the heart" as harmony, courage, wisdom, and imagination. It is the combination of these habits that allow leadership with and through love. By defining these habits of heart, leaders can recognize them in their existing practice and find ways to enact new practices that create schools of learning and belonging.

Keywords: leadership, love, schools, heart, humanity, preparation

OPEN ACCESS

Edited by:

Lauri Johnson,

Boston College, United States

Reviewed by:

Christa Boske,

Kent State University, United States

Martin Scanlan,

Boston College, United States

*Correspondence:

Mónica C. Byrne-Jiménez mcbyrnej@iu.edu

Specialty section:

This article was submitted to Leadership in Education,

a section of the journal

Frontiers in Education

Received: 07 August 2018 Accepted: 13 December 2018 Published: 09 January 2019

Citation:

Byrne-Jiménez MC and Yoon IH (2019) Leadership as an Act of Love: Leading in Dangerous Times.

Front. Educ. 3:117.

doi: 10.3389/feduc.2018.00117
Those of us who have already chosen to embrace a love ethic, allowing it to govern and inform how we think and act, know that when we let our light shine, we draw to us and are drawn to other bearers of light. We are not alone.

(Hooks, 2001,101)

\section{PREFACE}

These are complicated and complex times. Globally, populist waves are sweeping democracy aside and putting authoritarian rulers in its stead, the most recent being the presidential election in Brazil. Within the United Sates, the rise of White Supremacy and its acceptance into the halls-and coffers-of government is but only one example. In both contexts, we see increasing disrespect for and aggressive assertions of power over marginalized communities, along with the rise of neo-liberal economic and social policies that value profit over people. If public institutions, educational and otherwise, are functioning in a state of persistent crisis, then we must rethink the capacity of leaders and schools to stem this tide of fear and hate. What does it mean to reject these impulses and emotions and to embrace all members of a community? We argue that these times require a unique form of leadership that draws its strength-not from policies or regulations or authority, but from the heart in communion with others.

There has been recent and increasing attention in educational discourse on mindfulness (Yaron, 2015), the role of empathy in learning (see the recent special issue on "Learning with Empathy" in ASCD Express, September 2017), and social-emotional learning (e.g., Durlak et al., 2011). We support those conversations whole-heartedly (pun intended). We also believe that, for those conversations to have an impact on leader practice and leadership preparation, these ideas must be defined and integrated into a "conceptual framework." This task must be deliberative and taken up with care. We understand that the framework we offer here would need to be tested, improved, and expanded. We offer it in order to foster debate and more critical thinking of the relationship between leadership and love. It is the starting point for further discussion and study. 
In November 2016, Mónica Byrne-Jiménez gave her Presidential Address at the UCEA Annual Convention (ByrneJiménez, 2017). In that speech Dr. Byrne-Jiménez challenged faculty in educational leadership to reclaim love as an "active and important part of [their] leadership" (2). She spoke from a place where her intellectual vision for the field was inseparable from her heart-her belief in education, her values, and her commitments to justice. Subsequently, Irene Yoon wrote a response for the AERA Division A Newsletter (Yoon, 2017). Dr. Yoon added her thoughts to what "tough-minded, tenderhearted" leadership with love would look like. This essay builds on both of those to deepen the discussion, transform it into a dialogue, and urge the field of educational leadership to develop ways of leading that are more humanizing and responsive to the demands of growing up in the twenty-first century. As educators, and those who prepare future leaders, our job ultimately is to create schools that are places of joy, shelter, and learning.

We acknowledge and affirm that our views come from our specific journeys and identities. We are both cisgender women of color, the daughters of immigrants, from bilingual homes and family histories that continually cross borders. Mónica is a daughter of Mexican and Peruvian parents. Irene is Korean American, with a "hidden" disability. Both of us attended elite colleges and have spent our careers working for educational equity. Both of us work in organizations that often challenge how we move in the world and force us to make tiny, daily adjustments in order to thrive in those spaces. We exist in the in-between, often negotiating personal and professional identities out loud and in public spaces, like this one. What brings us together are not only our stories and the layers within them, but also how we tell them-with laughter and optimism, and a heartfelt recognition of both loss and pain. Our stories are inseparable from how we have experienced this current moment in history and the school leadership that it calls for.

The invitation to engage in this thought experiment, therefore, is by its very nature an integration of the academic and the personal, the mind and the heart. As scholars we are intellectual and emotional human beings. We ask you, then, to suspend judgments or expectations of traditional scholarly dialogue and join us in probing the limits of our collective understanding of leadership. By doing so, we begin to exercise new skills within the framework we propose and learn to act, think, and lead in new ways. This is not a typical way of dialoguing with our peers, and yet it honors our scholarly interests and reflects a commitment to finding ways of being that center our common humanity. Relatedly, we are scholars grounded in the work of schools and the lived experiences of practitioners. We see our work as connected to schools and classrooms and understand the tensions that emerge when we try to do this while simultaneously responding to the demands of our daily work in institutions of higher education. We hold that tension as part of our work and invite you to join us as we explore what a form of leadership that leads with love could look like.

Since we began writing this, there have been two more school shootings in the United States. Without action from legislators and political leaders, we mourn in the knowledge that more will occur even before this essay reaches you. In light of that tragedy, the need for re-visioning or re-imagining school leadership becomes even clearer. We dedicate this essay to the families who have lost a loved one through school violence.

\section{OUR PURPOSE}

In schools around the world, children arrive every day with a host of hopes and needs. Teachers arrive with their own hopes and needs. School leaders also arrive with their hopes and needs. For adults, these needs are personal as much as professional. These needs, for children and adults, are often ignored during the course of the school day and, perhaps, even the school year. Schools, and the people within them, are governed by rules regarding curriculum (scope and sequences, assessments), roles and responsibilities (in- vs. out-of-classroom personnel, students, parents), structures (schedules, committees), and systems (communication, discipline). These rules are, more often than not, inflexible and independent of those who implement them or those they serve. Leaders are tasked with making sure that these structures and processes operate efficiently and effectively, yet they are also keenly aware of the adults and children in their care.

One major issue that has resurfaced in the past decade is the need for social-emotional learning and trauma-informed care. Duncan-Andrade and Morrell (2008) have written of children who suffer from persistent (as opposed to post-) traumatic stress disorder. These are students who have significant social, emotional, and/or intellectual challenges because of long term, ongoing exposure to poverty, institutionalized racism, residential instability, immigration status, hunger, violence, and criminalization by court systems. These complex traumas are historical with transgenerational effects on students' neurological, social, and emotional development. Along with greater recognition of trauma and its long term negative impact on children's well-being is increasing acknowledgment that schools often retraumatize students with punitive discipline, lack of responsiveness, and disrespect (Shaia and Crowder, 2017). Despite the best efforts of some educators, schools often add further stress to students' lives. Students are resilient, but these are perilous times for children, for adults ill-equipped for the level of support children need, and for school leaders who must address holistic needs while improving achievement on standardized tests. In addition, leaders and staff may experience burnout and secondary traumatization [or "compassion fatigue," (Conrad and Kellar-Guenther, 2006)] from their own repeated exposure to students' or community trauma (Alisic, 2012). These issues are not new, but rather have been illuminated from recent dissemination of research in mental health, social work, counseling, sociology, cultural studies, and history. Though this literature has existed for some time, teacher and leadership preparation programs have not attended to the mental health needs of the children and of the adults who attempt to support them in chronically under-resourced systems. These are indeed dangerous times.

Leadership preparation programs have long reframed the role of school leadership from organizational management to 
instructional leadership (e.g., Poplin, 1992; Elmore and Burney, 1997). More recent efforts have emphasized principals as leaders for social justice and equity, focusing on addressing gaps in opportunity, achievement, and life outcomes that result from structural deficits (e.g., Dantley and Tillman, 2010). Modern leadership requires a new way of addressing the needs of children and adults. This is not to say that leaders need to do more, but rather that they need to do better. One element of that is to reclaim love as both a leadership strategy and as a leadership framework. Leaders must tap into the deep well of their love for children, for their work, and a deep belief in the power of education. To prepare this leader, preparation programs must also recover their capacity to love and their belief that leadership matters.

In this essay, we offer our thoughts on the current educational context and the new and unique pressures it is putting on educational leaders, school principals in particular. We take note of the confluence of forces that are focused on public education broadly and the implications for preparing leaders who can be joyful even as they engage in the hard work of educating children and preparing them with the skills and heart to be resilient, loving, community members. In order to enter this creative space-or thought experiment-we propose a leadership framework that re-centers elements of liberatory education (Freire, 1970; Darder, 1998), tempered radicalism (Meyerson and Scully, 1995), and loving epistemology (Liable, 2000; see also Capper, 2000). These scholars remind us that for too long organizations-schools in particular-have forced us to decide between our work and our humanity. Organizations employ several strategies to force a wedge not just within each of us, but among all of us. This distance, this othering of ourselves (Capper, 2000) from ourselves and from each other-or what Liable (2000) calls "institutional evil" - serves to further isolate us from the very thing that would make us stronger: recognition of each other's humanity. In contrast, these scholars urge us to resist those dissociative forces and find ways to maintain our integrity as inter- and intra-connected human beings. The work of leadership is messy and requires that we enter the murky world of relationships. At the core of our thinking-and feelingwe know that leadership does matter to children, schools, and communities around the country, indeed around the world. We must bring the full weight of our profession, our skills, our energy to bear on reclaiming the heart of leadership. Thus, we imagine a leadership grounded in radical, transformational, and sustained love.

\section{LEADERSHIP IN A COMPLEX WORLD}

We are not the first to call for preparing leaders for different, dynamic contexts (Kay and Greenhill, 2013). We do believe that new understandings from research and changing political contexts call for a constant re-examination of core values and principles of practice. Current leadership frameworks have evolved, slowly, over time. The world, however, moves at lightning speeds. The speed of high-frequency trading on the stock market, the speed by which something goes "viral," the speed by which we transmit cultural norms in discrete, easily digestible "memes", the fact that Facebook has created a new unit of time called a "Flick," which is one "five million six hundred thousandth of a second" (Coldewey, 2018, emphasis added), all highlight how nothing can stand in the way of time. In a world where time is compressed and information-real or notis shared in a blink of an eye, there is often little opportunity to explore the meaning of that information or how it might affect our existence.

How we measure time is not the only challenge. Because of social media and the 24-h news cycle we can know more about the world than ever before. And because of-or perhaps despite-the global economy we are increasingly aware of the human connections that exist around the globe. It is difficult to remain unmoved when we see the plight and determination of Syrian refugees or the devastation of floods in Bangladesh or the fear in the face of slaves mining for precious metals in Africa or the horror in the face of children who survived an attack on their school. Recent environmental movements and research have noted that the environmental disasters of climate change are occurring more rapidly than earlier predictions, and have stressed the belief that we are as connected to each other as we are to the Earth. Damage done to one part of the Earth affects us all.

We also exist in a more polarized political world. Rising nationalist and fascist movements endanger us all, especially the most marginalized who are the targets of this dangerous rhetoric. The need to work together for the common good is more important than ever. We work together-we care for each other-or we go down together.

If nothing else, the above clearly indicate that leadership can no longer be about the search for a "theory of everything" or a set of static "best practices." It is about envisioning multiple ways forward in order to prepare schools, teachers, and students for something they cannot see or predict. To do this, we must prepare leaders who are constantly adapting and thinking, planning for the future, yet who do not lose their footing or the "fierce urgency of now" (King, 1967). Crisis and uncertainty are also moments of great opportunity for social movements, democratic engagement, and collective action if we have the will to do the work that's needed. Leaders at all levels must be taught to reach across boundaries that divide us, that have been constructed and that we-all of us-continue to enable, consciously or not. In these contexts, leaders who embrace uncertainty and who understand that the journey has several unknown destinations will be able to prepare students for a myriad of possibilities.

In the following exploration, we center school principals as the specific perspective of school leadership for which we envision the nature of love and the habits of leading with love. Though we recognize that educational leaders are also in district offices, higher education institutions, classrooms, school boards, and state agencies; we adopt the K-12 school principal's perspective as an initial foray. We believe that the particular habits of love are likely to take different forms depending on the position and context of each leadership role, but similar values and feelings will likely hold true for all. 


\section{NATURE OF LOVE}

The capacity to love and to be loved may be one of the greatest gifts of humankind. It may also be one of our greatest challenges. Even to write in a scholarly journal about "love" makes some uncomfortable. In her speech, Byrne-Jiménez drew a distinction between the "love that you see in the movies" and a "courageous love that requires everything." This concept of an active, courageous love is grounded in a long line of critical writings from Thomas Merton to Paulo Freire to Gloria Anzaldúa. These writers, in many ways, see love as "rooted in a committed willingness to struggle persistently with purpose in our life and to intimately connect that purpose with what [Friere] called our "true vocation" - to be human" (Darder, 1998, 498). The search for love, therefore, is a search for our humanity.

In his book, Strength to Love (1963), Martin Luther King Jr. explores the depth and breadth of what he calls divine love. The title alone indicates that love that is sacred because it connects all living things, is not for the faint-hearted. Indeed, it is important to also acknowledge the connection between "armed love" (Freire, 1998) and the bright, clear anger at the core. The anger comes from witnessing oppression and injustice meted out on the most vulnerable. This courageous love we are speaking of is not despite the anger, it is beyond it. Keating (2013), in a similar spirit, developed a theory of post-oppositionality that moves beyond the us/them and either/or world view and seeks rather to adopt relational, transformative, and visionary ways of interacting. In order to reach a place of love, we must embrace our anger and use it to strengthen the heart for the long journey toward justice.

We, too, believe that love is an energy that emanates from within to shield and care for others. And since it comes from within, we must respect its power and be careful not to misuse it. Love, therefore, both takes risks and provides safety and sense of belonging. It motivates us to dream beyond our current limits and grow in body, mind, and spirit. It is a mutually accepted challenge that is reciprocal at its core and that requires kindness to oneself and others. Love is wise and wizened from the passage of time, yet joyful and flexible because it takes delight in the wonder of youth. Love experiences pain alongside others and heals through grace. It grows strong because it accepts that discomfort leads to new understandings. Love is impatient in the face of injustice while patient in its ability to forgive. Love allows us to resist hate.

Nee-Benham et al. (1998) described leaders' commitment to the "public process of loving, of behaving in a loving manner" (145). Love, often relegated to the private domain, comes to light in the leadership and relationships of schooling-with students, teachers, and families. It is the public nature of love and loving that elevates it as a way of leading and a purpose for leadership. It is powerful because it integrates the personal and the public in service to children. One need only walk through an elementary school and see children hug their teachers, or in the hallways of a high school and see the smiles of students as they enter a classroom, to know that love can live in schools. School leaders are gardeners who allow love to flourish in their buildings. Leadership in this sense encompasses a love characterized by care, respect, and responsibility (Hooks, 1994, 2001). Leadership as love means choosing to be truly present with children and adults in the building, and creating emotional and intellectual spaces to which children and adults can return each day (Kessler, 2000). It is not simply a disposition or feeling; it is an active practice that transforms schools into spaces of learning and belonging.

\section{HABITS OF THE HEART}

Love as an active form of leadership may seem to challenge the current state of schooling. School leaders have less time to develop thoughtful responses or may choose to respond in ways that privilege efficiency, effectiveness, and the cult of personality. The constant pull of external forces-policymakers, district superintendents, parents who know how to assert their privilege, business interests, to name a few-along with withinschool pressures and complications of bringing their school vision to life-puts school leaders under constant strain. As former teachers themselves, most leaders began their careers from a place of wholeness or, rather, where confidence and joy defined their work. Becoming a principal often is alienated from that place of joy and the current context works to undermine their confidence. Leaders, therefore, move through their days in a state of stress, balancing what the system says they must do vs. what their hearts tell them needs to be done. It follows, then, that leaders can become fragmented and without significant support are in danger of losing a vital piece of themselves. How then, do we return leaders to a place of joy in their work and maintain their personal and professional integrity? Thinking about this question in the context of the demands of school leadership, Hooks (2009) offers the development of habits of the heart. The skills and knowledges and values that make one "heartwhole" (217) are the foundation of a culture, a community, that shares a "language of healing, of hope, a language of dreams, a language of belonging" (223). In this section, we elaborate habits of the heart that constitute love as an active practice of leadership.

Palmer (1983) brought the minds, hearts, and souls of the learner and the learned together in his search of an educational system that cultivated wisdom and relationships. With a similar goal, we offer four habits of the heart that, when situated in the work of schools, become guiding principles of forms of leading. We describe leadership as love in terms of habits because they are ways of being that, with time, become accepted leadership practices. These habits, which surround and sustain leaders, form connections between vision and management, external pressures and internal conflicts, and between young people and adults, transforming the way we act and interact in our teaching, learning, and becoming. Like love, these habits of leadership are varied and unique and beautiful. And, like love, they require practice and attention.

These habits are grounded in what we have described previously as the nature of love. We draw from the work of many authors (some cited here), our experiences in and with public schools, and our identities as female scholars of color. We have filtered what we learned from these to derive this framework of four habits of the heart or the ways in which leadership with 


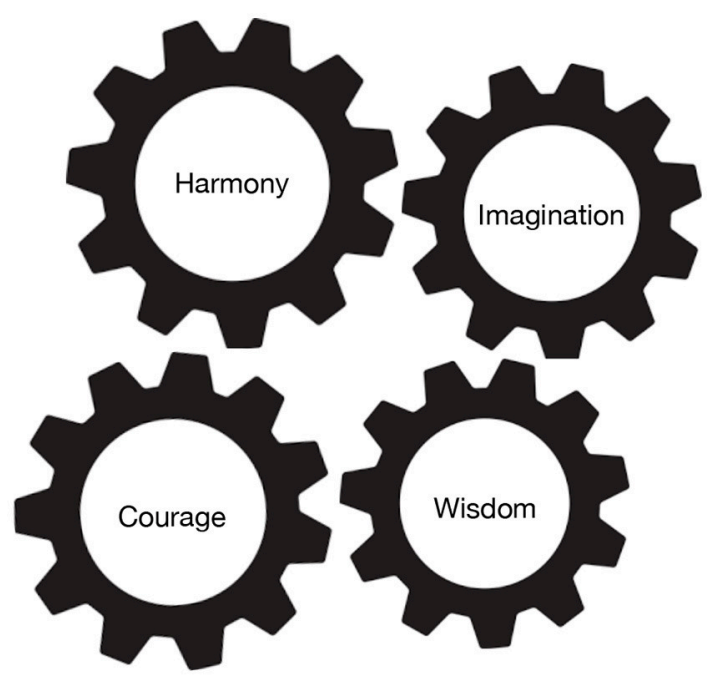

FIGURE 1 | Leadership habits of the heart.

love is enacted. We named these harmony, courage, wisdom, and imagination. In our minds these are like the gears of a watch: individual pieces that work in unison, each invaluable to the others (see Figure 1). In the next section we will attempt to define these habits and begin to identify how these might emerge in principals' work.

In order to make this thought experiment successful, we encourage you to read with an open heart and to imagine what these habits could look like in your own practice. What would your own life be like if you, and the leaders around you, all led with love?

\section{Harmony}

When I was a child, someone at school told me that you could melt a slug by putting salt on it. Skeptical of this piece of information, I went home, got the salt shaker from the kitchen, and went in search of a slug. When I came across one, I promptly sprinkled it with salt and watched it dissolve before my eyes. I cried at my handiworkat the violence I had committed-and vowed never to harm a slug again. To this day, I feel a deep sense of shame of having willfully killed that slug. I did not have the language or understanding to realize that, through my selfish act, I had upset the harmony of that garden, of that day.

Harmony is the tree bending in the breeze, yet snapping in the midst of a storm. Harmony is bringing your entire self and knowing that some will welcome while others will withdraw. It also means knowing how you bring your entire self in ways that may embrace or harm. It is an active state of being that requires strength, vulnerability, comfort with ambiguity, inquiry, and openness.

Indigenous elders would say that to walk this earth in harmony with oneself, others, and nature is to be truly human. Harmony requires that we embrace all the facets of our humanity, negative and positive, strengths and weaknesses, hopes and fear.
And in doing so we are able to see and embrace the humanity of others. It also implies that harmony is never truly achieved but something that we must envision and tend daily.

We often talk about "balance," and "finding balance" as if that were the answer to much of the chaos we experience. Balance implies an equilibrium between two things, weight and counterweight. But our lives are rarely so bifurcated, our choices and their consequences rarely so clearly delineated. We have multiple demands, responsibilities, roles, goals, identities, desires. Rather than balance, we need to seek harmony and to live in ways that bring harmony within ourselves (our past, our dreams, our doubts, our gifts), with others, and with the environment.

Much of the challenges that leaders face stem from organizational disharmony (Overvold, 1987), in which the uniqueness of each person is subsumed to the needs of the organization. To lead with/in harmony, educational leaders have to integrate their different selves in to a more whole existence. To lead in harmony also means that educational leaders have to integrate the different selves in the organization to create a new and stronger whole. Because leaders constantly negotiate among the needs of the organization and those of the people that make it up, they run the risk of creating disharmony in both. This is especially challenging when multiple needs, interests, roles (i.e., leader, teacher, partner, parent) and identities (i.e., race/ethnicity, sexual orientation, multilingual/cultural, ability) - their own and those of others-are clamoring for attention. Leading and learning, therefore, are physical, affective, and intellectual experiences woven together to create a new organizational tapestry. In the midst of this complexity, leaders must learn to exist in harmony with the communities they lead.

We challenge ourselves and invite our colleagues to engage in habits of harmony. If we were to imagine habits that indicated leadership that embraces harmony, we could envision principals who:

- Listen to their hearts

- Welcome their elders and youth

- Stay present in their community

- Invite others to connect and embraces the unknown

- Find laughter and joy in the small, everyday events

- Give expression to their creative selves

Harmony is a journey, and in a world obsessed with destinations, it can be easy to forget how to stay attuned to yourself, those around you, nature. And yet it can be the one constant that makes for complete and heartwhole leaders.

\section{Courage}

Studies that offer lenses for effective leadership often do not address how frightening leadership is, especially in a role that traditionally demands strength and displays of control. Allowing oneself to be vulnerable, to show fear or love, demands tremendous courage in the face of uncertainty and in a context of fetishizing quantifiable outcomes. Leaders might wonder how they will support teachers in challenging the status quo if they cannot control the outcomes of trying something different from district norms. In response to community trauma, school shootings, and natural disasters, leaders may wonder how they 
can prepare for the worst and not lead their communities to live in fear. Furthermore, leaders are challenged to confront casual or implicit racism, able-ism, genderism, or other forms of exclusion when doing so can cause conflict. Leaders even may have to make staffing decisions that are unpopular with faculty but are important for students. Below these questions, leaders may encounter whispers of self-doubt and fear.

It is often said that courage is not the absence of fear, but rather overcoming it. Leaders' courage to persevere comes from an unwavering commitment to a vision of schooling as an experience of collective growth, passion, and mutual care among adults, children, and community members. A community of courage is fundamental for leaders to create an environment of physical and emotional safety and to sustain school-wide commitment to a vision of equity and justice in the face of funding cuts, high turnover or reductions in staffing, bureaucratic processes that seem unfathomable, and inevitable disappointments when struggling to support all students well.

Withstanding these storms is a daily habit of courageous love. Because love thrives through connection, courage is made possible when leaders experience collective joy or tired laughter, through shared good days and through the excitement of moments seem magical-when schools and classrooms are responsive, creative, and playful centers of learning for adults and students. These moments fuel leaders' abilities to stay courageous on behalf of the heart of children and adults in their buildings.

Courageous love does not settle for mediocrity. Perhaps this is why we believe that leadership with love needs emotional and cognitive space to dream for more for their students and staff. When leadership is courageous for audacious and shared dreams, leaders can navigate and channel emotions-even fear-as tools to support, engage, empower others.

Principals who act with courage could exhibit some of these habits as they engage in leadership as love:

- Demand better, demand justice

- Laugh and cry alongside others

- Express outrage rooted in care for others

- Pursue dreams with faculty, staff, and parents

- Listen to anger and disappointment and respond in nondefensive, bridge-building ways

- Cultivate a strong sense of collective commitment among adults, among students, and within their communities

Courage, therefore, is what makes us become more than what we are and what love convinces us we can be. As leaders it allows us to leave the safe(r) confines of our individual existence and become part of a global community.

\section{Wisdom}

I grew up hearing my mother say, "Sólo sé que no sé nada" (the only thing I know is that I don't know anything). There were two important lessons embedded in that phrase: (1) knowledge is constantly changing and (2) humility. It is only now that I recognize these as wisdom-a wisdom handed down through generations of my family and grounded in love.
What we know — or think we know—is an elusive thing. Knowing the difference, including what remains to be known, is wisdom. It is more than what we think of as smarts or intelligence, although that can be an important piece. While knowledge derives from interacting with acceptable texts and experts, where empirically determined facts are the stock in trade; wisdom comes from understanding your own journey, learning from the pain and mistakes along the way, recognizing joy, and integrating those experiences into your worldview. In this sense, wisdom comes from developing a self-awareness and a self-love that is not narcissistic but compassionate toward the self and others (Nhat Hanh, 2015). Equally important is using that wisdom to ask others if you can accompany them on their journey, if only for a while. This offering is an externalization of love because it is "knowing," deep down in the recesses of our hearts, that our journeys are connected-across time, space, generations-and that the need to get there faster, ahead of others, is an empty quest.

Seeing the difference between knowing and wisdom requires a level of humility not valued in modern society. In a world that values certainty, control, fast solutions, winners-losers, having humility can be seen as weakness. What is often misunderstood is that true strength comes from being able to say "I don't know," or "I was wrong," or admitting that there are things to be learned from others different from yourself. Equally important, the humility to see the wisdom of those who have gone ahead or are following in our footsteps and/or caring steps of their own.

Educational leaders may rely on their prior success (they would not be school leaders if they had not already been successful somehow) and training as a measure of their qualifications. To be sure, having a depth of knowledge of leadership theory, practices, systems is a necessary, but not sufficient, part of leadership. Wisdom for leadership comes from being in the world, present in nature, with elders and children, and seeking clarity about your role in these realms. It requires a radical openness to loving new people, new places, new problems, new questions, new answers, new possibilities. Thus, to develop wisdom requires additional "work" on making sense of our internal and external contexts-relationships, history, vision, positionality. Wise leaders understand that simply knowing is not enough.

If we continue to define what leadership that reflects wisdom could look like, principals would exercise some of the following habits of love:

- Cultivate self-knowledge and awareness

- Be attuned to care of self and others

- Learn from experiences of others to create inclusive, responsive, and sustainable spaces

- Listen with care and compassion

- Understand that dreaming and acting are equally valuable

- Discern the relationships among internal and external politics, resources, and hopes

Wisdom is affirming in that it creates a different set of relationships within ourselves, with others, with the past and future, and with the environment. By embracing the limits of 
individual knowledge leaders can approach their work with humility and renewed purpose.

\section{Imagination}

Martin Luther King, Jr., in the face of the violence he saw and experienced, imagined a different kind of world centered in/around love and one in which everyone's dreams were precious. He believed in the possibility of this world so much that he fought for justice through non-violent resistance despite-or perhaps because of-the anger he must have felt every day of his life. James Baldwin reminded us over and over that to be a person of color in this country meant to be in a "constant state of rage." To lead for justice requires rage and hope that can only be lifted up by the ability to imagine something new, better, and more beautiful.

In this sense, imagination is powerful and creative: powerful enough to resist cynicism and creative enough to be truly free. Freedom is made of dreams, and dreams help us transgress what already exists. Imagination is transcendent, while being equal parts rebellious and visionary. When we imagine, as leaders, we draw on our other habits of the heart. It takes courage and wisdom to figure out how to dream, how to build.

For school leaders, imagination helps them to see past the limits and deficits of current ways of thinking about and interacting with children, youth, families, and communities. This then allows leaders to envision new ways of expressing their dreams, of working with teachers and staff, and of making schools centers of harmonious, courageous, and wise learning. This visioning builds on the individual and collective strengths of the community.

Imagination also makes room for empathy and understanding of perspectives different from leaders' own reality. As Maya Angelou said, "If one is lucky, a solitary fantasy can totally transform a million realities." To walk in another's shoes, to imagine a different way of seeing the world, helps leaders to build meaningful connections and tap into our shared humanity. It allows leaders to embrace a sense of wonder and curiosity about people, their thinking and learning, such that their behaviors communicate value and respect for whole and complex persons.

By cultivating a shared habit of imagining, leaders can help people find where they belong. Perhaps most important is the role of leaders in crafting and listening to the histories and stories of individual students, teachers, staff, parents, and their communities. These stories are sources of wisdom and identity, of shoring up courage with reminders of past success or resilience.

The final exploration of leadership as love would see principals who engender habits of imagination because they:

- Listen to and amplify the stories from the heart

- Build and share dreams

- Transgress the status quo

- Play out different perspectives

- Make intentional space for creativity and unstructured work

Leading with imagination, then, is about being hopeful and intentional about making collective dreaming a possibility for children and schools.

\section{INTEGRATING THE HABITS OF LOVE}

In the previous section, we explored harmony, courage, wisdom, and imagination as four habits of the heart that both define leadership as love and provide a set of practices that exemplify that leadership. We engaged in this "thought experiment" in order to push our own theorizing of how love can be enacted as a form of leadership. In our hearts and in our minds we know that this is the beginning of an idea. In the same spirit in which we developed this leadership framework-from a place of openness and interconnection-we embrace the four habits and their overlapping, mutually reinforcing energies. Rather than developing another theory, we want our thinking to "live" in harmony with existing leadership paradigms.

In our own exploration we rely on the work of other scholars and their re/framing of educational leadership. For example, early research by Scheurich (1998) and Murtadha-Watts (1999) began to introduce the role of love and spirituality within leader practices. Dantley's work on critical spirituality [Dantley (2003, 2005, 2010) i.e., 2003, 2005, 2010] and Alston's on servant (Alston, 2005) helped paved the way by making space in the leadership discourse for our spirit and humanity. Our habits are also linked to the work of other social justice scholars who helped the field focus on creating equitable schools for minoritized and under-served children. The critical analysis of existing school structures (e.g., curriculum, policies) as barriers to students' wellbeing and life chances raised the alarm for scholars and school leaders (Larson and Murtadha, 2002). Shields (2004) argued for the need for transformative leaders whose work was grounded in ethics and care. Such leaders overcome "pathologies of silence" (p. 118), including the erasure of difference, through moral dialogues that recognize the uniqueness of all individuals. More recently, Theoharis (2007) defined school leadership as rooted in justice, care, and empathy. A final area of synergy exists with culturally responsive leadership, which highlights the need for leaders to create inclusive schools for culturally diverse and non-majoritarian students and families (Johnson, 2014; Khalifa, 2018). The "responsive" nature of leadership honors community strengths, histories, differences, and needs. The scholars noted here, connect the core of their vision of leadership with the practices and purposes of schooling and education.

Too often our field debates the "rightness" of one perspective over another, with little room for theory building and evolution. In an effort to resist this trend, we offer our habits of the heart as concrete ways of understanding and demonstrating leadership that centers the humanity, knowledge bases, and traditions of individual leaders. Naming these habits allows us also to enter leadership spaces with intentionality and our humanity intact.

\section{CLOSING THOUGHTS ON LEADERSHIP AS LOVE}

It is fitting that we ended our discussion of these leadership habits of love with imagination, since we have asked you to imagine a different way of understanding and enacting leadership. You may also have noticed that we purposefully avoided some of 
the "standard" language used to describe leadership. In contrast, we tried using language steeped in the heart, in our imaginings of a different way of leading. It is our imaginations, in fact, that allowed us to engage in this thought experiment. You may have also found yourself feeling awkward or uncomfortable or asking about the evidence for this framework. We ask that you ask yourself why you are asking that! What skepticisms make a love-centered leadership seem impossible (or not) as a source of knowledge and practice? We must ask ourselves what in our training or discipline or assumptions makes a discussion of love and leadership so difficult, irrelevant, or unrealistic.

Ultimately, our invitation has been to engage in a thought experiment as a way to reflect on our pasts as well as our futures. In our individual and collective histories we must look for the stories of harmony, wisdom, and courage that, if we have been fortunate, have shaped our understandings of leadership. And in those stories, where were we allowed or encouraged to imagine a different way of being for ourselves and others? In what contexts did those stories emerge? How do we reshape and amplify those stories in our lives, personal and professional? What does embracing love as an active practice afford leaders in complex and sometimes painful situations?

Every day leaders are called upon to make decisions that impact the lives of children, families, teachers, and staff. Increasingly, school leaders are standing in the way of Immigration and Customs Enforcement officers or shielding their students in the aftermath of another school/community shooting or nurturing the fragile joy and promise of young people in the face of curriculum and assessments that alienate them. Every day, school leaders must choose between what is right and what is good, understanding that what may be right by organizational standards may not be good for students and their families. Without a clear and firm grounding in the habits of love, leaders may very well lose their humanity in these situations.

School leaders, however, cannot do it alone. Even as we have focused our thinking on the school principal, we know that there are larger systems and more powerful actors that also need to be a part of this new framing of leadership. Our current systems of

\section{REFERENCES}

Alisic, E. (2012). Teachers' perspectives on providing support to children after trauma: a qualitative study. Sch. Psychol. Q. 27, 51-59. doi: 10.1037/a0028590

Alston, J. A. (2005). Tempered radicals and servant leaders: black females persevering in the superintendency. Edu. Administration Q. 41, 675-688. doi: 10.1177/0013161X04274275

Byrne-Jiménez, M. C. (2017). 2016 Presidential Address: leading in dangerous times: leadership as an act of love. UCEA Rev. Winter 2017, 1-5.

Capper, C. (2000). Life lessons and a loving epistemology: a response to Julie Liable's loving epistemology. Int. J. Qual. Stud. Edu. 13, 693-698. doi: 10.1080/09518390050211583

Coldewey, D. (2018). Facebook Invented a New Time Unit Called the "Flick" and It's Truly Amazing. TechCrunch. Available online at: https://techcrunch.com/ 2018/01/22/facebook-invented-a-new-time- unit-called-the-flick-and-itstruly-amazing/ (Accessed January 22, 2018).

Conrad, D., and Kellar-Guenther, Y. (2006). Compassion fatigue, burnout, and compassion satisfaction among Colorado child protection workers. Child Abuse Neglect. 30, 1071-1080. doi: 10.1016/j.chiabu.2006.03.009 supervision and evaluation in $\mathrm{K}-12$ settings were not created with the habits of heart in mind. Nor were the promotion and tenure or accreditation processes in higher education created with heart. These systems make us believe that education is a zero-sum game and pit us against each other. In fact, they attack our humanity. In resistance, we would need to rethink how we prepare and support leaders in pre- and in-service learning contexts. We would also need to develop new ways of engaging with policy makers and politics that has both love and justice at the core. Lastly, we would need to embrace indigenous and other emerging methodologies that privilege harmony, wisdom, and multiple dimensions of reality as ways to develop human-centered questions, theories, and relationships.

As you can see, there is more work to be done to make this framework a reality. We are researchers, after all, and we cannot stay at the level of conceptualization when there are children and school communities in pain. We want to recognize and work with leaders who practice the habits of love to deepen our understanding of how this leadership survives in and perhaps transforms educational systems.

More importantly, we want to continue our inward exploration, as women of color who prepare the next generation of educational leaders and scholars, and how our histories strengthen and shape our own leadership. It is in the echoes of our pasts that we find our way forward. This journey to re/claim our stories and voices is as much an essential part of our scholarship as it is of our leadership. Because of this, we are confident that leadership is an act of deep, boundless, ancient, powerful love. We invite you to join us in this work!

There's power in love. Don't underestimate it. Don't even oversentimentalize it. There's power, power in love. - Reverend Michael Curry

\section{AUTHOR CONTRIBUTIONS}

MB-J and IY were equal contributors to the conceptualization and writing of this essay.

Dantley, M. E. (2003). Critical spirituality: enhancing transformative leadership through critical theory and African American prophetic spirituality. Int. J. Leadership Edu. 6, 3-17. doi: 10.1080/1360312022000069987

Dantley, M. E. (2005). African American spirituality and Cornel West's notions of prophetic pragmatism: restructuring educational leadership in American urban schools. Edu. Administration Q. 41, 651-674. doi: 10.1177/0013161x042 74274

Dantley, M. E. (2010). Successful leadership in urban schools: principals and critical spirituality, a new approach to reform. J. Negro Edu. 79, 214-219. Available online at: http://www.jstor.org/stable/20798344

Dantley, M. E., and Tillman, L. C. (2010). "Social justice and moral transformative leadership," in Leadership for Social Justice: Making Revolutions in Education, ed C. Marshall and M. Oliva (Boston, MA: Allyn \& Bacon Publishers), 19-34.

Darder, A. (1998). Teaching as an Act of Love: Reflections on Paulo Freire and His Contributions to Our Lives and Work. San Bernadino, CA: California Association for Bilingual Education.

Duncan-Andrade, J. M. R., and Morrell, E. (2008). The Art of Critical Pedagogy: Possibilities for Moving from Theory to Practice in Urban Schools. New York, NY: Peter Lang. doi: 10.3726/b12771 
Durlak, J. A., Weissberg, R. P., Dymnicki, A. B., Taylor, R. D., and Schellinger, K. B. (2011). The impact of enhancing students' social and emotional learning: a meta-analysis of school-based universal interventions. Child Dev. 82, 405-432. doi: 10.1111/j.1467-8624.2010.01564.x

Elmore, R. F., and Burney, D. (1997). Investing in Teacher Learning: Staff Development and Instructional Improvement: Community School District 2, New York City. New York, NY: National Commission on Teaching and America's Future and the Consortium for Policy Research in Education.

Freire, P. (1970). Pedagogy of the Oppressed. New York, NY: Bloomsbury Publishing.

Freire, P. (1998). Teachers as Cultural Workers: Letters to Those Who Dare Teach. Boulder, CO: Westview.

Hooks, B. (1994). Teaching to Transgress: Education as the Practice of Freedom. New York, NY: Routledge.

Hooks, B. (2001). All About Love: New Visions. New York, NY: Harper Perennial.

Hooks, B. (2009). Belonging: A Culture of Place. New York, NY: Routledge.

Johnson, L. (2014). Culturally responsive leadership for community empowerment. Multicult. Educ. Rev. 6, 145-170.

Kay, K., and Greenhill, V. (2013). The Leader's Guide to 21st Century Education: 7 Steps for Schools and Districts. Boston, MA: Pearson Education.

Keating, A. L. (2013). Transformation Now! Toward a Post-Oppositional Politics of Change. Urbana: University of Illinois Press.

Kessler, R. (2000). The Soul of Education: Helping Students Find Connection, Compassion, and Character at School. Alexandria, VA: ASCD.

Khalifa, M. (2018). Culturally Responsive School Leadership. Cambridge, MA: Harvard Education Press.

King, M. L. Jr. (1967). Beyond Vietnam: A Time to Break Silence. Speech delivered at Riverside Church, New York, NY. Available online at: https://kinginstitute. stanford.edu/king-papers/documents/beyond-vietnam (Accessed April 4, 1967).

Larson, C. L., and Murtadha, K. (2002). Leadership for social justice. Yearbook Nat. Soc. Study Edu. 101, 134-161. doi: 10.1111/j.1744-7984.2002.tb00007.x

Liable, J. C. (2000). A loving epistemology: what I hold critical in my life, faith, and profession. Int. J. Qual. Stud. Edu. 13, 683-692. doi: 10.1080/09518390050211574

Meyerson, D. E., and Scully, M. A. (1995). Crossroads tempered radicalism and the politics of ambivalence and change. Organ. Sci. 6, 585-600.

Murtadha-Watts, K. (1999). "Spirited sisters: spirituality and the activism of African American women in educational leadership," in School Leadership: Expanding the Horizons of the Mind and Spirit: 7th Yearbook of the National Council of Professors of Educational Administration, ed L. T. Fenwick (Lancaster, PA: Technomic Publishing Company), 155-167.
Nee-Benham, A., Maenette, K. P., and Cooper, J. E. (1998). Let My Spirit Soar! Narratives of Diverse Women in School Leadership. Thousand Oaks, CA: Corwin Press.

Nhat Hanh, T. (2015). How to Love. Berkeley, CA: Parallax Press.

Overvold, G. E. (1987). The imperative of organizational harmony: a critique of contemporary human relations theory. J. Business Ethics 6, 559-565. doi: $10.1007 /$ BF00383747

Palmer, P. J. (1983). To Know as We are Known: Education as a Spiritual Journey. New York, NY: HarperCollins Publishers.

Poplin, M. (1992). The leader's new role: looking to the growth of teachers. $E d u$. Leadership 49, 10-11.

Scheurich, J. J. (1998). Highly successful and loving, public elementary schools populated mainly by low-SES children of color: core beliefs and cultural characteristics. Urban Edu. 33, 451-491. doi: 10.1177/0042085998033004001

Shaia, W. E., and Crowder, S. C. (2017). "Schools as retraumatizing environments," in Linking Health and Education for African American Students' Success, ed N. M. Finigan-Carr (New York, NY: Routledge), 69-82.

Shields, C. M. (2004). Dialogic leadership for social justice: overcoming pathologies of silence. Edu. Administration Q. 40, 109-132. doi: $10.1177 / 0013161 X 03258963$

Theoharis, G. (2007). Social justice educational leaders and resistance: toward a theory of social justice leadership. Edu. Administration Q. 43, 221-258. doi: 10.1177/0013161X06293717

Yaron, L. (2015). Mindfulness in the Classroom: A How-to Guide. Education Week. Available online at: https://www.edweek.org/tm/articles/2015/11/10/ mindfulness-in-the-classroom-a-how-to-guide.html (Accessed November 10, 2015).

Yoon, I. H. (2017). Considering the Future of U.S. Public Schooling: PresidentElect Trump, ESSA, and Educational Leadership. Division A Newsletter of the American Educational Research Association. Available online at: http:// aeradivisiona.org/invited-commentary.html (Accessed January 29, 2017).

Conflict of Interest Statement: The authors declare that the research was conducted in the absence of any commercial or financial relationships that could be construed as a potential conflict of interest.

Copyright $\odot 2019$ Byrne-Jiménez and Yoon. This is an open-access article distributed under the terms of the Creative Commons Attribution License (CC BY). The use, distribution or reproduction in other forums is permitted, provided the original author(s) and the copyright owner(s) are credited and that the original publication in this journal is cited, in accordance with accepted academic practice. No use, distribution or reproduction is permitted which does not comply with these terms. 